Keywords to War belongs to a genre of books that aim to expose contemporary public language and rhetoric to critique. In reviewing Zournazi's book, I've also dipped into several others of the genre, two of which the author herself cites as inspirations for this current work.

The book is a response to how the Western world has reacted to the 2001 attacks on the twin towers in New York, how these attacks

\title{
hollow words
}

MARY ZOURNAZI

Keywords to War: Reviving Language in an Age of Terror

Scribe, Carlton North, 2007 ISBN 9781921215223

RRP $\$ 27.95(\mathrm{pb})$ have 'been fed by a climate of fearful and terrorizing politics'. (1) Accompanying this climate of fear and terror - a manufactured climate, some would say-has been 'an ever-increasing violation of language and, at the same time, the violation of human dignity and life'. (1) Zournazi, like many others, is disturbed by the corruption of language in times of war. As she admits, this is not a new phenomenon. However, through a combination of technology's ubiquitous tentacles 'and the holy alliance between new forms of power, morality and terror ... a more intense violation of language' (2) has occurred. The book is 'an urgent call to understand how much of our language has become surrounded by fear and suspicion, by the annihilation of meaning and by the deadening of its use'. (3)

One cannot disagree with the aspiration of revitalising our language. To achieve it, Zournazi has selected thirty-four keywords to war 'as tools to help us think past terror and to restore a revitalised language into our everyday lives and political environment'. (3) Each keyword appears as a short essay, beginning with a sometimes complex etymological history and progressing to its often distorted meanings in the present. Further, in the introductory chapter 
'The Power of Words', the author writes that 'by connecting thoughts and feelings that are alienated by usage and wrenched out of place, we may be able to approach and define all humanity in more compassionate and veridical ways'. (8) Finally in this chapter we learn that the revival of language should enable us 'to perceive freedom, to act ethically and be morally responsible. To do all this requires us not only to think about language, but also to feel and to express it, in every facet of our daily bread that is language, to keep alive our shared communication by this choice and our use'. (10)

Yes, language is our daily bread, no more so than for readers of and contributors to Cultural Studies Review and like you, I desperately wanted Zournazi to convince and inspire me, through her language, that the book had achieved its abstract aims 'to perceive freedom, to act ethically and be morally responsible', through revitalising the language. Yet, by and large, it didn't. This is not to say that there are not gems within, beginning with her substantial choice of war words, ranging from the obviously negative-_anguish', 'bad faith', 'despair', 'evil', 'hate', 'terror'-through the great range of ambivalent words English has to offer us'allegiance', 'community', 'humanity', 'freedom', 'responsibility', 'suffering'- to the positive and enlightening-'belief', 'compassion', 'courage', 'dignity', 'empathy', 'justice', 'love' and 'trust'. To Zournazi's credit, many of these words do not immediately leap onto one's list of top-ten terms associated with the war on terror. Yet there was one word whose absence leapt out at me and I remain curious as to why it was excluded: 'security'. Surely this word, in its contemporary and historical usages, would contribute to Zournazi's canvas of how our language has become debased, has become part of the Newspeak lexicon, as Orwell might have it.

Let's take a couple of examples to illustrate what works and what doesn't in Zournazi's text. A friend drew my attention to an earlier book, Collateral Language: A User's Guide to America's New War. ${ }^{1}$ The books, although different in some respects, have overlapping aims and so it seems fair to compare them. Collateral Language, like Keywords, is a collection of essays. They were:

written to expose the tyranny of political rhetoric used to justify 'America's New War' ... Just as 'collateral damage' describes military damage in addition to the intended targets, 'collateral language' refers to the language war as a practice adds to our ongoing lexicon as well as to the additional meaning certain terms acquire during wartime. We call language a terrorist organization to illustrate the real effects of language on citizens, especially in times of war. ${ }^{2}$

One of the main differences between the two is that Collateral Language is a collection of fourteen essays, exploring a few of the same terms as Zournazi does ('evil', 'freedom', 'justice' and 'terrorism'). The essays are longer than Zournazi's entries and are able to delve more deeply into the terms' contributions to the 'language wars' that both books are concerned with. The words 'terror' (used by Zournazi) and 'terrorism' (used by Collins) seem appropriate as a means to discuss what has troubled me 
about Keywords to War. Keywords is more literary and abstract than Collateral Language, not so intent on analysing and contextualising the history and politics of the language emanating from the 'belly of the beast', the United States. Yet, it is this very specificity that I craved and missed in Keywords to War. In her 'terror' entry, Zournazi writes that 'terror and terrorism have become complicated political terms that are difficult to differentiate'. ${ }^{3}$ As with all the entries, we firstly read of its etymology. I learnt that its early uses in Middle English (fourteenth logi century) 'referred to the fear or terror of God' and that this divine power was coupled historically with the word 'territory'. 'Territory', Zournazi writes, 'is thought to be a derivative of terra, earth, and the original use suggests a derivation from terrere, to frighten; hence, territory was a place from which people were warned off' ' ${ }^{4}$ Thus, from its earliest uses, there has been a connection between terror and land, between those who already control it and others who employ violent means to take what they regard as theirs.

Terror's contemporary meanings are wellknown. Terror as 'an act of producing fear and dread in a culture is a contemporary form of social control'. As Zournazi observes, it becomes conflated with good and evil, "where good embodies those who fight terror, and evil refers to those who perpetrate acts of political violence'. She notes the ubiquity of the terms 'terror' and 'terrorism'- the enemy could be anywhere, and everywhere. One cannot disagree with Zournazi's statement that the war on terror has 'acquired a global lexicon for describing acts that uphold its ideas of justice and the perpetuation of violence. Thus, living in an age of terror requires the consideration of how we use this language, and the reality of its effects in everyday life and politics. 5

Turning to John Collins's essay on terrorism in Collateral Language, we find an approach that I found more informative and satisfying than the language of broad brushstrokes that is consistently present in Keywords to War. How can we challenge 'terror-rhetoric' if we are not aware of its history (political as well as etymological)? Collins does this through pointing to what has remained constant about what constitutes 'terrorism' in the decades since the 1970s when the term was first framed, even though 'a variety of individuals and groups have occupied the role of "terrorist". ${ }^{6}$ For, as Collins argues, the immediate and almost total acceptance of the "terrorism craze' 7 in the United States and its allies in the aftermath of 9/11 would not have been possible if the ideologues in the 1970s, 1980s and 1990s (for example Richard Nixon, Ronald Reagan, George Shultz and the Bushes) 'had not done such a successful job of defining "terrorism" in the first place'.

The final section of Collins's chapter reveals what many of us already know: that what is defined as an act of terrorism depends upon who is doing the defining, or non-defining. Basically, now, as in the 1970s, "terrorism" involves organized opposition to the policies of the United States or its allies'. ${ }^{9}$ Simple. Well, no. And this is what is so insidious about the language of the 'war on terror' and related terms. Those sufficiently powerful to evoke this language have a vested interest in not defining it. Collins cites from speakers from the West 
and the Rest at the United Nations General blue-green algae choking the life out of our Assembly's weeklong 'Debate on measures waterways.

to eliminate international terrorism', held

1-5 October 2001. The incommensurability between those nations supporting the USA and those whose representatives had definitions and experiences of terrorism that included 'dire poverty' and 'Western imperialism', was frightening. ${ }^{10} \mathrm{I}$ use this example to make the point that in order to have a chance at working with others to right any of the many wrongs in this world, we need the tools to help us understand it. Language is the tool by which we learn about the world, and act in it. Keywords to War and Collateral Language aim to provide us with linguistic and analytic tools to better understand the current Age of Terror and its accompanying language debasement. Reading these two books in tandem made me realise that it was not uplifting, literary prose that I needed, but a more concrete, getting-our-hands-dirty analysis of the "real effects of language"11 in the present, as well as (hi)stories of how words have changed their meanings as part of the war on terror.

Don Watson's Death Sentence is one of the books Zournazi says acted as an inspiration for Keywords to War. ${ }^{12}$ Watson, too, has a passionate concern for the deadening of our language, particularly as it manifests in our institutions and from the mouths of public figures. Watson practises what he preaches. His language is bursting with life, in contrast to the many managerial and market-oriented terms he derides, such as 'issue', 'consultant', 'account- Australian Jewish Community, her research ability', 'outcome' and so on, which, he says, interests include the diminishing status of official 'clog the language and cut us off from thought, multiculturalism in Australian politics, the feeling and possibility', ${ }^{13}$ like an infestation of positive and negative ways local ethnically
In its afterword, Keywords to War tells us that exploring language and its everyday effects:

might be conducive to making the world a more peaceful place, in which case, the task would then be to think of a politics of love that speaks of truth and greater justice, an idea that may yet be a nascent [sic], but perhaps because of this we can restore our faith in humanity and the world, as we are more resilient than we can ever know. And language can prove it. (186)

Reading, and re-reading, Zournazi's concluding thoughts led me to ponder how one assesses the power of the written word. The author wants Keywords to War to inspire and empower her readers to also believe in the fine sentiments expressed in the quotation above, for who would not? Unfortunately, this reader remains unconvinced that the task Zournazi has undertaken, exemplary though it is in some respects, can lead to the kind of global transformations she suggests need to occur.

BARBARA BLOCH is a part-time tutor and lecturer in Social Inquiry in the Faculty of Humanities and Social Sciences at the University of Technology, Sydney. Following a doctorate on the role and effects of Zionism and Israel on the 
diverse communities negotiate difference, the intersections of gender, class and ethnicity in current debates, the rise of religion in our public life and the concomitant urgent need to demonstrate the significance of secularism for a civil society. In a previous life she worked as a researcher in the vocational education sector.

1. John Collins and Ross Glover (eds), Collateral Language: A User's Guide to America's New War, New York University Press, New York, 2002.

2. Ibid., pp. 1-2.

3. Ibid., p. 167

4. Ibid., p. 166

5. Ibid., p. 169

6. John Collins, 'Terrorism', in Collins and Glover, p. 162

7. Ibid., p. 163

8. Ibid., p. 164

9. Ibid., p. 165

10. Ibid., pp. 166-8.

11. Ibid. p. 6.

12. Don Watson, Death Sentence. The Decay of Public Language, Vintage Books, Sydney, 2003.

13. Ibid., p. 183 